\title{
HISTORICAL MEMORY, EMBODIED IN THE SOCIAL SPACE OF MINSK, AND ITS INFLUENCE ON THE FORMATION OF NATIONAL AND EUROPEAN IDENTITY OF BELARUSIANS
}

\author{
Larissa Titarenko \\ Belarusian State University, Department of Sociology, \\ Nezavisimosti av. 4, 220050 Minsk, Republic of Belarus \\ E-mail: larisa166@mail.ru
}

\begin{abstract}
Historical memory embodied in a social space of Minsk represents "cultural signs" of several different epochs. In fact, the historical past of Minsk up to the beginning of the XIX century can be considered as the process of construction of its European identity. In this aspect, the XIX century demonstrated a shift to Russian euro-asianism, while the soviet history was a unique attempt to construct the universal Soviet identity with only a few features of the national culture. The contemporary epoch gives Minsk a unique chance to simultaneously increase both European and national identity of Belarusians.
\end{abstract}

Keywords: city Minsk, historical memory, national identity, social space.

DOI: $10.3846 / 2029-0187.2008 .1 .32-45$

\section{Introduction}

The goal of this paper is to describe the influence of the city of Minsk, the capital of the Republic of Belarus, to the contemporary citizens of Belarus, and especially the citizens of Minsk. This influence can be viewed in the field of construction of their identity (or identities). In more details, I would like to discuss to which extent the historical memory of Minsk is presented in its current architecture, its toponymy, its spirit, and how the citizens of this city feel about this history and the present day of Minsk. The object of research is the city of Minsk: its buildings, monuments, names of the streets viewed from the point of their attitudes to the citizens of this city.

Two methods were primarily used: (1) historical analysis - to describe the history of Minsk paying attention to the events that mostly influenced the historical memory of people, and (2) sociological survey of the citizens of Minsk - to check their attitudes towards the current city.

The paper is written within the Pierre Bourdieu theory about symbolic significance of the social space. Some other theories (mainly, about post-soviet transformation and historical memory) have been used as well (Therborn 2002; Schliogel 2006; Anderson 1991).

The problems of constructing the national identity and the role of the capital city in this process are not new in social sciences. On the one hand, many scholars from post- 
communist states analyzed the issues of ethnic and national identity (Jurij Arutjunjan, Leokadia Drobizeva, Boris Porshnev, Zinaida Sikevich, Tatjana Stefanenko, Victor Tishkov), collective and group identity (Victor Avksentjiev, Anatolij Zuravlev), and a special attention was paid to the post-soviet identity (Jurij Kachanov, Jurij Levada, Elena Danilova, Vladimir Yadov, etc.). In Belarus, these issues were researched in relation to the formation of Belarus identity (Sergey Dubenecky, Cheslav Kirvel, Vladimir Melnik, Irina Bugrova), and a positive vision of "we-image” of Belarusians was painted (Tatjana Vodolazskaya, Victor Kirienko). At the same time some authors showed the obstacles in this process of formation a national identity (Valyantsin Akudovich, Igar Bobkov, Grigorij Minenkov) as this problem closely connected with the strengthening the sovereign nation-state. On the other hand, there are few publications about capital cities that focused on their role in the process of formation national identity. Mainly, the books are published only about the famous capital cities: Moscow in Russia, Prague in the Czech Republic, London in Great Britain, etc. (Blair Ruble, Karl Schliogel), while other capital cities (Minsk among them) were not even mentioned1.

For these reasons, a combination of research issues of national identity and capital cities within the framework of historical memory of each nation seems to be very important for the Republic of Belarus - a country that is still in search for its original way and place in history.

\section{The concept of the historical memory}

The process of the formation of national identity is closely connected to some other important problems, historical memory among them. According to Zhan Toshchenko (Тощенко 2000: 123), historical memory of a nation is directly connected with the socio-cultural identity and therefore it is connected with the national identity because the latter is based on the national culture (language, folklore, myths, stereotypes, etc.). The way how a particular society views its history reflects the fact how this society functions in the present situation (what are its values and norms), and how it is oriented to its own future.

For this reason, one of the key concepts of our paper is a concept of historical memory. For the purposes of this paper we consider historical memory to be a kind of

1 In 2006 an architect A. Klinau published a new fotoalbum about Minsk with the intrique title “Горад СОНца” (The Sun City of Dreams). Regardless of a limited edition, this book has become the most famous publication about Minsk among the foreigners. In this album Minsk was painted as a city restored after the WWII as a communist "dream city" that however functioned only as a "triumphal arch" to Moscow, the major soviet dream city. This album became the first document to show the visual effect of Minsk to its population and discover the mechanism of "myth construction". Partly sharing Klinau's opinion about Minsk as a “dream city”, I stress a bit different idea: majority of current citizens take this image for granted and do not have any doubts about Minsk as a postwar reification of a "city of the sun" (at least its soviet edition). 
the public consciousness that is related to the past and its representation in the present (in written, or materialized and oral, or spiritual forms).

Historical memory contains the knowledge of history as a whole (primarily, related to the own country and nation), understanding the relationship between the past and the present, and the attitude of the current generations to their historical past.

The scholars and politicians of post-soviet states pay a significant attention to the historical memory and use this category as a means of reinterpretation of the soviet history, as well as the history of any particular post-soviet region or republic. Those states that demonstrate the disruption with the soviet past build a new vision of their history only on the pre-soviet past. Even Russian scholars (Историческое сознание...1991) try to restore the ties with the past that were lost in the soviet epoch: they search for identity in the Viking times of the construction of the Russian state, Ivan the Terrible, or Peter the Great. On the contrary, in some countries the scholars and politicians build their future on the basis of their soviet past.

Historical memory can significantly influence the present situation (national consciousness, national identity, and so on) in case some particular historical events have been important for the country, stay alive in the memory of the people and can be used as a pattern or a model for the contemporary situation. It may happen spontaneously or it can be stimulated by mass media, propaganda as a whole. For example, in the history of Moscow there are some outstanding events that are well-known for citizens of Moscow and are the objects of common respect and glory of the Moscow times: Patriotic war against Napoleon in 1812, German defeat under Moscow in 1941 during the Great Patriotic war, restoration of the main Cathedral, etc. The first and second above-mentioned events generate the feelings of Russian patriotism, and any monuments or names related to these events remind the citizens of Moscow about the heroic past of their city. The third event relates to the religious renaissance in Russia and therefore it can be used for overcoming the post-soviet spiritual crisis and for the moral upbringing of the nation. If some events are in the historical memory of the people, it means the nation respects these events and wants to keep them alive.

According to a particular country, the main historical events, as Lev Gudkov from Russian Public Opinion Research Center discovered (Гудков 1997: 12), can go far in the past like a personality of Peter the Great in Russian history who is the most popular hero today, according to Russian public opinion surveys or be close to the present day like anti-soviet 1989-1990 revolts in the Baltic states that helped them to obtain independence. As a materialistic embodiment, some monuments can be erected (monument to Peter the Great in Moscow in early 1990s) while some others can be removed (monuments to Alexander Pushkin and Ivan Chernyakhovsky in Vilnius in the early 1990s, monument to the Soviet soldier in Tallinn in 2007). The more country respects its own past, the more historical events are refreshed in the historical memory of its population.

There is no national history if the nation does not know it. Historical facts (or events) are not significant and not visible if they are not kept in the memory of the nation. Historical knowledge exists to the point of our interest to it and to our ability to connect this history with the present-day life. In general, the nation can always navigate its fu- 
ture on the basis of its past: its evaluation, reflection, re-thinking. That is why historical memory helps to keep the past, involve the past into the present life, and receive some historical lessons from rethinking it.

For the Republic of Belarus, which gained its independence and sovereignty in 1991, historical memory is especially important: analysis of the past can help to evaluate the present situation and select the path to the future. Historical memory of Belarusians keeps lots of positive things that can be connected to the current situation and therefore can help to evaluate today's events within the historical framework. Also, knowledge of history can provide the citizens of Belarus with some special (national) energy that is necessary for Belarus nation to develop itself.

Of course, it does not mean that all historical events or personalities are equally important for historical memory. However, in order to make a difference between events, it is necessary to know them. Only after learning the past we can understand what was good, and what was wrong there. In the future, it will be necessary to reassess the past again, as it is a non-stop process of construction and reconstruction of the history with the help of the memory within political, spiritual and psychological context of the present day.

Historical memory is often focused on the things that can be referred as historical heritage. From this aspect, historical heritage can be presented in several forms: material objects (buildings, monuments, any objects of the past), folklore (myths, fairy tales, and proverbs), language and communication, and cultural space where all the above-mentioned objects are situated and where people as native bearers of language and culture communicate.

\section{Historical memory of Minsk}

If we emphasize historical memory as a historical heritage, there is a possibility to overestimate everything related to the past, consider the past as a depository for the valued ideas and sacred objects, symbols of our glory and great respect. It is in this sense Polish sociologist Jan Szczepanski (Щепаньский 1969: 45) pointed out that cultural heritage is always an object of idealization and means of integration of social groups, especially during the crises. Minsk is a city with a very rich historical past. It was founded as a fortress in Polock principality and first mentioned in the Chronicles in 1067. Then Minsk belonged to the Great Duchy of Lithuania, Tsarist Russia, and the Soviet Union. Minsk was a center of a small principality, then a center of voivode district, a governor city, and the capital city since 1919.

Minsk was destroyed several times during many wars; it was occupied seven times by the troops of five foreign states, but survived. Having such a dramatic history, there is no surprise that only few historical buildings and symbols survived. Nevertheless, until now there are such places in the historical space of Minsk as Upper (Verhny) Market, Lower (Nizny) Market, and Trinity suburb: these three are among the most well-known and favorite places of contemporary citizens. Minsk has its own coat of arms since 1591. During the Soviet days it was not in use as a symbol of "alien ideology". However, after 1991 this coat of arms has been activated as a symbol of historical past of the city and as 
a cultural heritage. On the same basis, Minsk city hall was restored: therefore the very fact that Minsk has got Magdeburg right since 1499 has been historically recognized, and a new bridge between the past and present has been constructed.

Like many other European cities in the past, Minsk was a multi-ethnic city for several centuries: ancestors of contemporary Belarusians, Russians, Poles, Lithuanians, Jews, Tatars, Germans as well as some other nations and ethnic groups lived there. During the Polish rule, majority of citizens in Minsk were Jews, while the very city was rather small. Only by the very end of the XIX century the population of Minsk was close to hundred thousand people, due to two railways that connected Minsk with the center of Russia and Western Ukraine. All these ethnic groups contributed into the cultural diversity of Belarus, and the signs of their life could be easily found on the city map until recently: names of the streets (such as Tatar suburb, German street), religious buildings (synagogues, churches, mosques, monasteries).

Native population that gave the name to this country in the XIX century, Belarusians, lived mainly in the countryside. Cities were multiethnic where Belarusians made up a small part. Minsk, like many small and middle-sized cities in this region, consisted of Jews who served as merchants and craftsmen, low layer and middle layer of the traditional middle class. According to the historical data (Гісторыя Мінска 2006: 234), Minsk population was half-Jewish during the whole XIX century. Because of such ethnic composition it is not a surprise that a number of synagogues in Minsk was higher than a number of Christian churches (Orthodox, Catholic and Protestant) taken together. Rich Jewish merchants donated lots of money to support traditional religious life in the city; therefore in Minsk there existed synagogues of all kinds in the early XX century.

The XX century dramatically changed the country and Minsk: many historical signs disappeared, and symbols of a new epoch were erected. Minsk became a typical provincial soviet city. Being enormously destroyed during the last world war, where almost one third of the country's population was lost, Minsk was restored as a new city: it became a soviet symbol of the victory in this war. Lots of new monuments and names appeared on the city map. Minsk grew very fast and became more and more Belarusians city: according to the official statistics (Население...2006: 27), percentage of ethnic Belarusians living in Minsk grew from 17 in 1897 to almost 80 in the beginning of the XXI century.

In 1909, as Zachar Shibeka described (Шыбека 1994), the national structure of Minsk population was the following: Jews $-43,3 \%$, Russians $-34,8 \%$, Poles $-11,4 \%$, Belarusians $-8,2 \%$, Tatars $-1,3 \%$, and Germans - 0,9\%. However, during the WWI, a number of Belarusians grew because of growing numbers of refugees.

During the WWII Minsk lost a significant part of its population. Actually, since the post-WWII time, Minsk was totally populated by first-generation urban inhabitants who brought habits and traditions of the village life and their traditional mentality with them. For former Belarusians peasants the move to Minsk was a great success and great challenge: it was a road to another civilization. They felt in Minsk like a nobleman who recently had moved from the province to Paris, or like individuals moved to La Sitta del Sole (Campanella) by the will of a wizard (and this wizard had a personal name: Stalin). 
As it was explained in my previous paper, published in Russia (Титаренко 2006: 59), Minsk was a real "city of Sun" for the first post-war generation of the city inhabitants: it was a place where all the hopes and dreams about safe urban life replete with warm apartments in state living houses, central heating and water taps, good public transportation, state stores and markets, public dining-rooms and other miracles from fairytales, might become a reality. Their previous miserable rural life made displacement to Minsk an unbelievable miracle, and they appreciated this change very much, regardless of any "temporary difficulties and shortages", as Communist propaganda explained. They were proud of themselves and especially proud of the city where they lived since then.

Today's Minsk looks like a modern city that is still growing fast, as well as its population: newcomers from smaller cities and villages like to come to the capital and stay here as Minsk provides them lots of possibilities. As the proportion of indigenous population is growing, it is especially important for them to learn the history of Minsk: otherwise they cannot enjoy the historical heritage and contribute to cultural development. However, the problem is not so simple, as some groups of the citizens are more interested in the close-to-earth things and improvement of their own life conditions rather than in the history of the city. Their historical memory can be poor. Special attempts are necessary to help them to discover rich history of Minsk and keep this history visible to all.

Summarizing unique and sad history of Minsk it is worth stressing that out of its rich multicultural historical heritage only a few buildings and streets survived, such as Trinity suburb, Rakov suburb (partly), a few buildings from the XIX- early XX century on Kirova street (former Magazinnaya), Marxa (former Podgornaya), Frunze (former Hospital street), and a couple of Orthodox churches in the cemeteries. As a historian Anna Smolskaya mentioned (Смольская 2007: 141), “architectural heritage needs preservation, understanding and harmonious bringing it to the social and cultural structure of contemporary Minsk”.

\section{Historical names on the city maps: toponymy of streets and buildings}

The city plan was reconstructed several times during its history, and so the names on the map of Minsk. In the XVI-XVII centuries, when Minsk belonged to PolishLithuanian Commonwealth, Catholic financial support for architecture was dominant. That is why many streets and districts had religious Catholic names. However, in the XIX century, when Minsk belonged to Russian empire, the toponymy of the city was russified. Instead of Catholic names, many orthodox names appeared to be connected to the new Orthodox churches and monasteries. However, all of them disappeared in the 1919-1934 as "ideologically harmful”, and only a few religious names were restored in Minsk (in cases when they belonged to small non-significant streets or were far from the center).

In the end of the XIX century some street names mirrored the cemeteries or regions nearby: Jewish and Moisey streets near Jewish cemetery, Luteran and German 
streets near German cemetery, Archierey street near the place of living of Orthodox Bishop. Currently, these religious names are not on the map, but some ethnic connections of streets and their previous inhabitants exist: in the same districts there are Karl Liebknecht street and Jerusalem street (however, citizen of Minsk hardly recognize this connection, as these ethnic groups do not live there).

The names of the streets connected to the WWII can usually be found in the center, close to the Victory Square.

In general, toponymy of Minsk is still oriented to the soviet cultural pattern and therefore they represent the "soviet face" of the city, especially the face of the "city-hero". It is not a coincidence that foreign tourists usually make pictures of the street places with the Soviet names: Karl Marx street, Engels street, Lenin street, Communist street, not even mentioning the names of the soviet writers and former Communist party and soviet military leaders (Gorky street, Kalinin street, Kirov street in the very center of Minsk; Goloded street, Gamarnik street, Tuchachevsky street, etc.).

The analysis of 40 names of streets in Minsk within the so-called "second ring" (the center) gave the following results (Table 1).

Table 1. Toponymy of major streets, parks, squares

\begin{tabular}{lcc}
\hline Cultural dominant basis & Number in Minsk & \% among all names \\
\hline Soviet & 24 & 60,0 \\
\hline World War II & 4 & 10,0 \\
\hline Writers, poets (all periods) & 5 & 12,5 \\
\hline Historical names & 4 & 10,0 \\
\hline Post-Soviet changes & 3 & 7,5 \\
\hline Total & 40 & 100 \\
\hline
\end{tabular}

Changes of names on the city map clearly represent the direction of symbolic and political influence of Minsk toponymy on the citizens. As Pierre Bourdeau expressed, "power means capability to give names". The current regime perfectly uses this capability: in 2005, "on the eve of the 60th anniversary of Soviet victory in the great patriotic war", as it was declared, two most important and largest avenues were renamed. As a result, names of the first Belarusian printer Skaryna and a famous popular communist leader Petr Masherov disappeared from the center of Minsk. Instead, these avenues were called as follows: Independence avenue and Avenue of Winners (in both cases it means Second World War).

Therefore, the symbolic influence of toponymy and the ability to impress people with the "heroic past of Minsk" increased. This is a perfect example how Minsk can contribute to the construction of a national identity.

\section{Historical names on the city maps: monumentality in Minsk as a form of commemoration}

Public monumentality appeared in Minsk during the centuries of Grand Duchy of Lithuania. However, such monuments were removed during the XIX century and were 
substituted by the Russian monumentality. Two world wars actually contributed a lot into the process of changes. Therefore currently only the Soviet monumentality is well represented in Minsk.

The pattern of monumentality in Minsk still represents the Soviet identity and hardly contributes to the construction of new national identity of Belarusians. Also, this pattern hides the historical past of Minsk both from its inhabitants and the tourists.

A small comparative research of monuments in the center of Minsk disclosed that among 15 monuments, three are devoted to the WWII heroes, three - to the soviet official leaders (including Lenin and Felix Dzerzhinsky), eight - to the writers and scholars (among them five were opened after 1991, and two are invisible in the university yard). Only four monuments really represent Belarusian national culture. Such form of commemoration does not meet national interests and does not help in representing national identity of the country.

A similar pattern is represented by current religious buildings. Currently, there are 37 religious buildings in Minsk, among them 13 belong to Orthodox churches and 5 belong to the Catholic confession (they are situated mainly in the historical center, while Orthodox churches were also built recently in all suburbs of Minsk). As for 16 Protestant religious buildings and two synagogues, they are settled down relatively far from the center. This "religious geography of buildings" represents the official state attitude to the historical differences that religious denominations played in the history of Minsk, in other words, they represent a political will to keep only Orthodoxy and Catholicism for representation matters and therefore support the idea that national identity is based only on these two.

\section{Multi-functionalism of contemporary Minsk and attitudes of citizens: interest to the history of Minsk}

Images of the past in the social space of Minsk represent cultural signs of different historical periods: from the Great Duchy of Lithuania (GDL) until independent Republic of Belarus. Not all of these signs are equally visible: such symbols of GDL as the castle and the City Hall were destroyed in the XIX century (as I have mentioned earlier, the City Hall was restored a couple of years ago, while the castle will never be restored). The symbols of Poland were destroyed almost two centuries ago as well: many buildings that earlier belonged to the Catholic churches were converted to the Orthodox ones, and the Catholic names of the streets were deleted from the map. In the XX century, however, other changes have occurred and many signs of traditional Russian culture disappeared from Minsk, as well as synagogues and mosques.

Our sociological survey, conducted in winter-spring 2007 in Minsk by sociologists of Belarusian State University, confirmed the fact that citizens of Minsk are not very interested in the history of the city in general (see Table 2).

As we can see, only 15\% know Minsk history well and are interested in it. Almost 45\% answered that they are rather interested; it probably means that they watch some TV programs about Minsk, read newspapers and books related to it, but are not actively oriented to learn more about the city. Three out of ten respondents said they are not 
Table 2. Are you interested in the history of Minsk? (in percentage terms)

\begin{tabular}{lc}
\hline Yes, very much interested & 15.5 \\
\hline Yes, rather interested & 44.3 \\
\hline Difficult to say & 6.2 \\
\hline No, rather not interested & 30.2 \\
\hline Not at all interested & 3.2 \\
\hline No answer & 0.4 \\
\hline
\end{tabular}

interested in this history; quite possible that they do not know it, as usually there is a correlation between the level of knowledge and the level of interest. Overall, six out of ten said they are somehow interested in Minsk history. Taking into account the fact that respondents are the citizens of Minsk, 60\% of those who are somehow interested is not much. Typically, in the well-known world capitals (London, Paris), almost all the population expresses some kind of interest to the city where they live (Girouard 1985). So in case Minsk pretends to be a world city, or at least if citizens of Minsk would cultivate their European identity (that is quite practical for a European state), the system of historical education and the whole process of education must be reconsidered.

\section{Multi-functionalism of contemporary Minsk and attitudes of citizens: interest to the history of the Great Patriotic war}

However, there are some historical events officially forwarded to the forefront and backed by the historical memory of the nation. These events play a significant role in the process of the construction of national identity in contemporary Belarus. Under the current influence of post-soviet transformation and globalization, what are the symbols of the past that still can be of great importance for Belarusians? Undoubtedly, these symbols are connected with the wars for independence. In two former soviet republics - Russia and Belarus, - this is the Great Patriotic war. According to the public opinion surveys, as Georgij Illichev wrote (Ильичев 2007), Russians consider this war as the major event of the XX century. As Russian sociologist Gudkov clearly explained (Гудков 1997: 13), every family keeps the memory of the Great Patriotic war because their relatives participated in it, and many soviet people died. Actually, this war is the "most important element of the positive collective identification" that helps to evaluate both the past and the present of soviet and post-soviet generations. Not only old people, but younger generation as well keep this memory. It means that the historical experience of elder generations has been transformed into symbolic capital of the current generations.

As for Belarusians, the Great Patriotic war considers to be the most positive event in the soviet history of Belarus: Belarusians would not have survived as a nation without the victory in this war. This is the message of the majority of the scientific and public interpretations of this war. In other words, the Great patriotic war is the strongest tie between the citizens of current Belarus, as well as the most important connection between Belarusians and other nations of the former Soviet Union. Due to these reasons, 
the Great Patriotic war is constantly in the focus of attention of the government, mass media, culture, etc. In 2005 a special discipline titled “The Great Patriotic war” was introduced into the curriculum of secondary schools and universities as one of the obligatory courses in the country. Therefore, any other historical events are considered as less important. In Minsk it means a special governmental attention to the monuments devoted to the Great Patriotic war, names of the streets devoted to the war heroes, several scientific, cultural and sport competitions devoted to the Victory day, etc. According to this strong attitude, all the other historical events of the country and the city are treated as not so important in comparison to the Great Patriotic war. As a result, this period of history of Minsk is also interpreted as the most significant.

As it is clear from Table 3, the majority of the respondents selected the characteristics of Minsk as a "hero city of the Great Patriotic war" more often than any other characteristics of Minsk.

Table 3. What is applicable to the characteristic of Minsk from the following?

\begin{tabular}{llllll}
\hline No & Characteristics & Yes & Partly & No & D/k \\
\hline 1 & City with a rich history & 56 & 34 & 8 & 2 \\
\hline 2 & Typical soviet city & 27 & 50 & 20 & 3 \\
\hline 3 & Hero city of WWII & 76 & 16 & 6 & 2 \\
\hline 4 & Modern European city & 17 & 55 & 26 & 2 \\
\hline 5 & Multicultural city & 18 & 46 & 34 & 2 \\
\hline 6 & Provincial city & 4 & 29 & 65 & 2 \\
\hline 7 & Trade and economic center & 36 & 45 & 17 & 2 \\
\hline 8 & Cultural center & 58 & 34 & 5 & 3 \\
\hline
\end{tabular}

Our results confirmed that for three out of four respondents Minsk is primarily a hero-city of the Great Patriotic war. It means that the city plays an important political role in the process of patriotic education of youth. This function reflects the current political situation and also confirm the fact that Minsk is still a primarily a city with the soviet history.

However, the same Table 3 shows that more than a half of respondents view Minsk as a city with a rich history. However, it is not clear whether respondents mean all ten centuries of this history, or only the last century (or two). It is possible to interpret this characteristic in many directions. However, regardless of the meaning of this figure (56 per cent), only 1,5\% of the same sample said they know the history of Minsk quite well, and another $9 \%$ rather well. All in all, only one out of ten confirmed his/her good knowledge of Minsk history. Almost a quarter of the respondents said they know history more or less (probably, they still remember some facts from the secondary school), and other $22 \%$ admitted their low level of knowledge. What is really negative is missing answers: 44\% simply missed this question. It is hardly believable that they could miss the question in case of high level of historical knowledge; on the contrary, it is quite possible that there was nothing to answer about Minsk history. At best, their knowledge 
was not quite good, as usually respondents give clear answers to the questions where they can evaluate their knowledge as good and very good.

In fact, the level of historical knowledge is not much higher in Russia as well. According to Toshchenko (Тощенко 2000: 126), in a representative survey only 17\% of Russians admitted their good knowledge of history, 56\% selected middle level ("soso"), and $15 \%$ bad knowledge.

As we can see, the system of education, mass media, literature and science have to combine their efforts in order to improve the level of historical knowledge of the nation. Otherwise, there is a challenge and a threat for the coming generations to become "Ivans who do not remember their roots", as the Russian proverb says.

\section{Political role of Minsk and its influence on national identity}

Today's urban image of Minsk clearly demonstrates two faces:

(1) a heroic historical past of the city (however, this is primarily a reflection of the soviet history: Minsk - hero of great Patriotic war, while a historical past of Minsk almost disappeared);

(2) a prosperous present-day of the city (however, without a cultural break with the soviet past, so the "current prosperity and power" are based on the alleged soviet prosperity of Minsk in the 1950-1970th).

These two images have been embodied in various architectural forms, monuments, and names on the map of Minsk. They reflect different roles of Minsk in representation of the past and present history of Belarus and Minsk itself.

What differentiates Minsk from many other former soviet capitals? Minsk did not destroy its previous soviet image, soviet symbols; instead, Minsk took them as useful instruments for political reinforcement of the present regime. One can read the name of Stalin on the wall of the military college, or visit the Stalin's line memorial near Minsk. Cultural discrepancy with the pre-soviet history is not emphasized; however, cultural continuity with the soviet past is taken for granted.

On the one hand, all official spaces in Minsk demonstrate the "power of the soviet past”: the Presidential residence is former Communist party headquarters, House of Parliament is the Soviet Government and Supreme Soviet place, KGB and Constitutional court are in their old houses keeping their previous names. Only City Hall was restored recently: however, citizens do not know its history and do not connect it with the past self-governance of Minsk.

On the other hand, the new buildings representing the post-soviet reality (supermarkets, private banks, casinos, McDonald's, etc.) are also mushrooming on the city map, these new forms contribute into construction of a new identity that is better accepted by the new generation (those who look forward to Europe and do not look back to the soviet past). Plurality of forms and styles in Minsk makes the city image eclectic, however, this multi-faceted image better fits the reality and even attract interest of foreign tourists to visit Minsk.

Currently, the historical memory of Minsk is used in cases when it can reinforce the present political rule and represent the "successful present-day" of independent 
Republic of Belarus. Therefore, huge buildings have been built recently (sport palaces, Orthodox churches, new national library, as well as fashionable living houses and boulevards, supermarkets, hotels, banks).

The key idea of all new buildings and public spaces is to demonstrate to the masses that the political regime is strong and powerful, that Belarus is a successful welfare state. Minsk represents abundance; its citizens are satisfied and happy.

According to representation of this political role, as Andrej Ekadumov (Екадумов 1998) stressed, Minsk is not a periphery (or province) of Europe (as the European Union assumes it) or Eurasia (as Russia considers it). This is a real European and world center. That is why there is almost nothing to assimilate from outside: Minsk and Belarus have their own patterns of modernity, of cultural and economic development, of architecture, etc. Minsk and Belarus take these patterns from their history, however only a small part of the historical heritage is in use.

The political identity of Belarus is constructed as a prosperous country that can teach its neighbors how to be successful; the political identity of the city can be articulated as a power and self-satisfaction.

\section{Conclusions}

On the basis of our analysis it is possible to say that currently Minsk perfectly plays its symbolic and political roles in immortalizing the history of the Great Patriotic war as the most important basis for the historical memory of Belarusians. Accordingly, the history of Minsk and its social space are actively used in the process of constructing and representing a post-communist national identity based on the history of war and on the present-day events such as construction of the national library, new monuments, sport palaces, banks, etc.

However, this selective attitude to the Minsk's past represents primarily a political will of the ruling elite to impress the citizens and tourists with the beautiful, but politically biased image of Minsk: first, a soviet city-hero, second, a capital of prosperous and stable modern state.

Potentially, Minsk can contribute to the construction of new national identity in many other ways and represent the rich history of this multi-ethnic and multi-cultural city. As Rubanov estimated, "an image of Minsk as an assembly shop of a big country has to be dismissed by the image of Minsk as a center of education and science (История Минска 2006: 48)”. Such new image would probably better fit a global role that Minsk would like to play on the international arena, because this role must be supported by European or even global identity of citizens.

Younger generation of Minsk inhabitants (that is less influenced by the soviet past than other generations) is more critical to this image of Minsk while the majority of citizens are totally under the official monumental symbolic and political impressiveness of their capital city. 


\section{References}

Aleksandravičius, E. 2006. "Post-Communist Transition: The Case of Two Lithuanian Capital Cities”, International Review of Sociology 2: 347-360.

Anderson, B. 1991. Imagined Communities: Reflections on the Origin and Spread of Nationalism. London: Verso.

Girouard, M. 1985. Cities and People. New Haven: Yale University Press.

Schliogel, K. 2006. “The comeback of the European cities”, International Review of Sociology 2: 471-486.

Therborn, G. 2002. "Monumental Europe: the National Years. On the Iconography of European Capital Cities”, Housing, Theory and Society 19: 26-47.

Екадумов, А. 1998. «Бездомная нация из европейского дома» [online] [cited 26 September 2006]. Available from Internet: <http://viscult/by/com $>$.

Гудков, Л. 1997. «Экономические и социальные изменения: мониторинг общественного мнения», Информационный бюллетень 5: 10-15.

Гісторыя Мінска. 2006. Мінск: Беларуская Энцыклапедыя.

Население Республики Беларусь. 2006. Статистический сборник. Минск: Министерство статистики.

Историческое сознание: состояние и тенденции развития в условиях перестройки. 1991. Москва: Академия социальных наук.

Ильичев, Г. 2007. «Десять побед, которыми гордятся россияне», Известия науки 16 января.

Смольская, А. 2007. «Город старый, город новый», Беларуская думка 1: 10-15.

Титаренко, Л. Г. 2006. «Символическая роль и политические функции Минска в репрезентации белорусской национальной идентичности», Социум и власть 4: 55-63.

Тощенко, Ж. Т. 2000. «Историческое сознание и историческая память. Анализ современного состояния», Новая и новейшая история 4: 123-132.

Шыбека, 3. В. 1994. Мінск: странииы дореволюиионной жизни. Минск: Беларусь.

Щепаньский, Я. 1969. Элементарные понятия соииологии. Москва: Прогресс. 


\title{
ISTORINE் ATMINTIS, IKŪNYTA SOCIALINĖJE MINSKO ERDVĖJE, IR JOS ITTAKA BALTARUSIŲ TAUTINĖS BEI EUROPIETIŠKOSIOS TAPATYBIŲ FORMAVIMUISI
}

\author{
Larissa Titarenko
}

\section{Santrauka}

Istorinè atmintis, įkūnyta socialinėje Minsko erdvejje, reprezentuoja kelių skirtingų epochų „kultūrinius ženklus“ ir nuo XIX a. pradžios gali būti suprantama kaip europietiškojo tapatumo formavimosi procesas. XIX a. i̇sigalèjus rusiškajam euroazijatiškumui, visa sovietinė istorija tapo unikaliomis pastangomis sukurti universalų sovietinį tapatumą su keletu blankių nacionalinės kultūros bruožų. Šiuolaikinė epocha teikia galimybę augti tiek europietiškajam, tiek baltarusiškajam tautiniam tapatumui.

Reikšminiai žodžiai: istorinè atmintis, tautinis tapatumas, socialinė erdvé, Minskas. 